\title{
Microbial activity responses to water stress in agricultural soils from simple and complex crop rotations
}

\author{
Jörg Schnecker ${ }^{1}$, D. Boone Meeden ${ }^{2}$, Francisco Calderon ${ }^{3}$, Michel Cavigelli ${ }^{4}$, R. Michael Lehman ${ }^{5}$, \\ Lisa K. Tiemann ${ }^{6}$, and A. Stuart Grandy ${ }^{2}$ \\ ${ }^{1}$ Department of Microbiology and Ecosystem Science, University of Vienna, Vienna 1090, Austria \\ ${ }^{2}$ Department of Natural Resources and the Environment, \\ University of New Hampshire, Durham, NH 03824, USA \\ ${ }^{3}$ College of Agricultural Sciences, Oregon State University, Corvallis, OR 97333, USA \\ ${ }^{4}$ Sustainable Agricultural Systems Laboratory, USDA-ARS, Beltsville, MD 20705, USA \\ ${ }^{5}$ North Central Agricultural Research Laboratory, USDA-ARS, Brookings, SD 57006, USA \\ ${ }^{6}$ Department of Plant, Soil and Microbial Science, Michigan State University, East Lansing, MI 48824, USA
}

Correspondence: Jörg Schnecker (joerg.schnecker@univie.ac.at)

Received: 2 April 2021 - Discussion started: 3 May 2021

Revised: 9 July 2021 - Accepted: 26 July 2021 - Published: 26 August 2021

\begin{abstract}
Increasing climatic pressures such as drought and flooding challenge agricultural systems and their management globally. How agricultural soils respond to soil water extremes will influence biogeochemical cycles of carbon and nitrogen in these systems. We investigated the response of soils from long-term agricultural field sites under varying crop rotational complexity to either drought or flooding stress. Focusing on these contrasting stressors separately, we investigated soil heterotrophic respiration during single and repeated stress cycles in soils from four different sites along a precipitation gradient (Colorado, MAP $421 \mathrm{~mm}$; South Dakota, MAP $580 \mathrm{~mm}$; Michigan, MAP $893 \mathrm{~mm}$; Maryland, MAP $1192 \mathrm{~mm}$ ); each site had two crop rotational complexity treatments. At the driest (Colorado) and wettest (Maryland) of these sites, we also analyzed microbial biomass, six potential enzyme activities, and $\mathrm{N}_{2} \mathrm{O}$ production during and after individual and repeated stress cycles. In general, we found site specific responses to soil water extremes, irrespective of crop rotational complexity and precipitation history. Drought usually caused more severe changes in respiration rates and potential enzyme activities than flooding. All soils returned to control levels for most measured parameters as soon as soils returned to control water levels following drought or flood stress, suggesting that the investigated soils were highly resilient to the applied stresses. The lack of sustained responses following the removal of the stressors may be because they are well in the range of natural in situ soil water fluctuations at the investigated sites. Without the inclusion of plants in our experiment, we found that irrespective of crop rotation complexity, soil and microbial properties in the investigated agricultural soils were more resistant to flooding but highly resilient to drought and flooding during single or repeated stress pulses.
\end{abstract}

1

\section{Introduction}

Future climate scenarios predict increasingly frequent and extreme weather events, with both more severe droughts and flooding (Stocker et al., 2013). How these shifts in precipitation patterns affect agricultural systems is of special interest due to their roles in food security and global carbon and nu- trient cycling, both of which are likely to alter with climate change (Bowles et al., 2018).

Soil microorganisms, which drive nutrient and carbon cycling, will regulate how soils respond to these shifts in precipitation patterns. Both drought and flooding influence microbial processes and functions (Schimel, 2018), which in turn may feedback to plant-soil interactions (Canarini and 
Dijkstra, 2015; Kaisermann et al., 2017). For example, reduced water content in soils can cause microbial death or sporulation and thereby strongly reduce overall microbial activity (Herron et al., 2009). Even under less severe reductions in soil water content, microbial activity decreases since diffusion, microorganisms' main means of substrate transport (Bailey et al., 2017; Schimel, 2018; Tecon and Or, 2017), is reduced in concert with reduced connectivity of microorganisms and soil organic matter and nutrients (Linn and Doran, 1984; Schnecker et al., 2019). Lower soil water may also lead to higher soil solute concentrations, enhancing osmotic stress for microorganisms (Killham and Firestone, 1984; Wood, 2015).

As soils recover from drought and are rewetted, numerous studies have observed an increase of respiration rates that often exceed control levels for days after rewetting (Birch, 1958; Fierer and Schimel, 2002; Li et al., 2010). This "Birch effect" (Birch, 1958) is associated with an increase of available dissolved organic carbon (DOC) through microbial death during drought (Schimel, 2018) or caused by the lower drought sensitivity of extracellular enzymes compared to microorganisms, which results in enzymes solubilizing soil organic matter (SOM) that is not taken up by the inactive microbes until rewetting (Schimel, 2018; Steinweg et al., 2013).

Under water-saturated conditions, soils run the risk of oxygen $\left(\mathrm{O}_{2}\right)$ deficiency leading to less efficient microbial energy generation and production of potent greenhouse gases (Berglund and Berglund, 2011; Linn and Doran, 1984; Randle-Boggis et al., 2018; Smith et al., 2003). Rewetting can displace $\mathrm{CO}_{2}$ from soil pores, causing a degassing that can in turn affect microbial metabolism (Calderón and Jackson, 2002). In agricultural systems, anaerobic conditions or repeated changes from wet to dry conditions can lead to nitrous oxide $\left(\mathrm{N}_{2} \mathrm{O}\right)$ production and alter the cycling of bioavailable nitrogen (Bowles et al., 2018; Davidson, 1992; Muhr et al., 2008).

How microorganisms respond to stress determines if specific microbial processes and functions can withstand or be buffered against stress. Resistance to stress is the ability of microbial communities to withstand prevailing stressors (Allison and Martiny, 2008) and reduce the amplitude of the stress response. Along with resistance, stress response can be defined by resilience, which characterizes the duration of the stress response. A resilient microbial community quickly returns to pre-stress levels (Allison and Martiny, 2008). In addition to these initial or one-time microbial reactions to abiotic stress, microbial communities may also adapt to reoccurring stressors (DeAngelis et al., 2010; Evans and Wallenstein, 2012) by progressively reducing the initial amplitude and/or duration of the stress response with each recurring stress event.

Adaptation to recurring stress is more likely to occur with greater microbial diversity, which often correlates with functional redundancy (Girvan et al., 2005) and the probability that members of the community have physiological traits that improve their stress responses (Griffiths and Philippot, 2013). Land management history can affect soil microbial diversity, which in turn can affect how soil responds and recovers from disturbances (Jackson et al., 2003). Microbial diversity in agricultural soils has been shown to increase with crop rotation complexity (Tiemann et al., 2015; Venter et al., 2016) and especially the introduction of cover crops (Vukicevich et al., 2016). These management practices also result in increased soil microbial biomass (McDaniel et al., 2014) and organic matter (Ding et al., 2006; McDaniel et al., 2014), while reducing agroecosystem nitrogen loss and improving crop yields under climate stress (Bowles et al., 2020). While there is evidence to support a link between crop rotation complexity and resilience of crop yields under climate stress such as drought or flooding, it remains unclear if microbial communities in these complex cropping systems are also resilient.

Drought and flooding are contrasting forms of stress for microorganisms and challenge them in very different ways; however, drought and flooding are usually studied simultaneously. Flooding in particular is usually studied only as rewetting events after drought (Birch, 1958; Schimel, 2018). Therefore, classic drought-rewetting experiments provide only limited insight into microbial response to the individual stressors: drought and flooding.

The aim of this study was to test microbial responses to one-time and recurring episodes of drought or flooding and whether and how these responses are moderated by a history of crop diversification. In a laboratory incubation we manipulated water regimes in soils from four long-term crop rotation experiments across the USA. At each site we selected a low (two crops, "simple rotation") versus high (three or more crops, "complex rotation") diversity rotation for comparison. The sites range from low (Colorado) to intermediate (Michigan and South Dakota) and high (Maryland) precipitation. Soils from different regions were chosen to examine whether potential adaptations to drought and/or flooding depend on historical climate. Replicate sets of soil samples were either alternately dried and rewetted to optimum moisture content ("drought"), alternately flooded and dried to optimum moisture ("flooding"), or maintained at a constant water content (control). We monitored heterotrophic soil respiration $\left(\mathrm{CO}_{2}\right.$ production) during five moisture stress cycles. Additionally, we determined microbial biomass, enzyme activities, and nitrogen pools and fluxes during the first and last stress cycle in soils from sites with the precipitation extremes.

\section{Material and methods}

\subsection{Sampling sites}

Soils were collected in October 2015 from long-term crop rotation experiments at USDA-ARS sites in Akron, Colorado (CO); Beltsville, Maryland (MD); and Brookings, South Dakota (SD) and at the W.K. Kellogg Biological Station 
(KBS) Long-Term Ecological Research Site (LTER), Michigan (MI). All sites maintain field experiments that include treatments with different rotation lengths. Composite topsoil samples from within the first $10 \mathrm{~cm}$ were collected from three (Colorado) to four (Maryland, South Dakota, Michigan) field plot replicates in simple (two crops in rotation) and complex rotational treatments (three or more) each. Soils from Maryland, South Dakota, and Michigan were sampled under corn and those from Colorado were sampled under wheat. Site descriptions can be found in Table 1 and in Cavigelli et al. (2008), Lehman et al. (2017), Tiemann et al. (2015), and White et al. (2019).

\subsection{Experimental setup}

After sampling, soils were sieved and shipped on ice to the University of New Hampshire and refrigerated at $5^{\circ}$ for less than 1 week. Approximately $30 \mathrm{~g}$ soil from each replicate plot (three from Colorado and four from each of the other sites) were weighed into $100 \mathrm{~mL}$ plastic cups resulting in a total of 27 cups per replicate from Colorado and Maryland and six for South Dakota and Michigan. Soils in the microcosms were adjusted to $50 \%$ water holding capacity (WHC). One set of cups was covered with Parafilm and kept at constant water content by replacing evaporated water once a week and after every $\mathrm{CO}_{2}$ measurement over the course of $165 \mathrm{~d}$. One set of cups was subjected to drought and another to flooding (Fig. 1). All soil microcosms were kept at a constant temperature of $25^{\circ}$. Microcosms for the drought treatment were allowed to gradually dry out over the course of $3 \mathrm{~d}$, kept at peak drought for $4 \mathrm{~d}$, and slowly brought back to $50 \%$ WHC by adding one third of the evaporated water every day for $3 \mathrm{~d}$ to avoid even short time flooding effects. Microcosms for the flooding treatment were gradually brought to $100 \%$ WHC but not higher to avoid submerging the soils in water over the course of $3 \mathrm{~d}$, then kept at $100 \%$ WHC for $4 \mathrm{~d}$, and then kept open to dry back to $50 \%$ WHC again within $3 \mathrm{~d}$. Drought and wetting were repeated after 2 weeks of the soils being held at constant WHC. Soils were subjected to a total of five stress cycles during the first $125 \mathrm{~d}$ of the total $165 \mathrm{~d}$ incubation period. Soils from all sites, rotations, and water treatments were set up twice. To determine long-term recovery, one set was subjected to only one stress cycle and was kept at $50 \%$ WHC for 6 weeks after the stress. The second set was subjected to a total of five stress cycles. For each combination of rotation complexity, water treatment, and harvest we had three replicates from Colorado and four from Maryland, South Dakota and Michigan.

To determine soil carbon and nitrogen pools and microbial enzyme activities in soils from Colorado and Maryland with the lowest and highest MAP, respectively, we set up 10 sets of each of the control, drought, and flooding treatments for each of the sites. One set from each site was destructively harvested before, at the peak of, right after, 2 weeks after, and 6 weeks after the first and last stress cycle (Fig. 1).

\subsection{Soil carbon, water content, water holding capacity, and $\mathrm{pH}$}

Samples for total carbon and nitrogen analysis were dried at $60^{\circ}$ for $24 \mathrm{~h}$ and finely ground in a ball mill before subsamples were packed in tin capsules and total carbon measured on an elemental analyzer (Costech Instruments ECS 4010) (Paul et al., 2001). Total carbon content as well as water holding capacity were determined for all soils prior to the incubation experiment. Water holding capacity was measured by determining soil water content after saturating the soils with water in a funnel with filter and letting the excess water leach gravimetrically for $2 \mathrm{~d}$ while preventing evaporation by covering the funnels with Parafilm (Paul et al., 2001). Water content and $\mathrm{pH}$ were determined for all soils before the start of the incubation and during the 10 destructive samplings for Colorado and Maryland soils. Water content was determined gravimetrically in sample aliquots that were dried in a forced draft oven at $60^{\circ}$ for $24 \mathrm{~h}$. Soil $\mathrm{pH}$ was determined in a $1: 5$ soil to water mixture using a Mettler Toledo SevenEasy $\mathrm{pH}$ Meter 20.

\section{$2.4 \mathrm{CO}_{2}$ and $\mathrm{N}_{2} \mathrm{O}$ production}

$\mathrm{CO}_{2}$ production was measured daily for the first week, twice a week after that, and just before the destructive harvests. For respiration measurements, cups were temporarily closed airtight with lids fitted with rubber septa that served as a sampling ports. We took $3 \mathrm{~mL}$ of the headspace using a syringe immediately after closing the sample and after $30 \mathrm{~min}$ to $2 \mathrm{~h}$, depending on the incubation duration within the experiment and the carbon content of the samples; longer incubation times were used at the end of the experiment and for soils with lower total carbon contents. The gas samples were immediately injected into an infrared gas analyzer (LICOR LI 820) to measure $\mathrm{CO}_{2}$ concentration. Rates of $\mathrm{CO}_{2}$ production were calculated from the increase of $\mathrm{CO}_{2}$ concentration in the headspace of the jar over time, accounting for the jar and syringe volume and temperature and assuming a linear increase between the two sampling time points. $\mathrm{Cu}$ mulative respiration was calculated by using respiration rates measured at a certain time point and multiplying that flux by the number of days to the next respiration measurement and summing all resulting $\mathrm{CO}_{2}$ emissions (Grandy and Robertson, 2007). To compare cumulative respiration among sites, values are expressed as $\mu \mathrm{g} \mathrm{CO} \mathrm{CO}_{2}-\mathrm{C}$ per gram soil carbon.

For the determination of $\mathrm{N}_{2} \mathrm{O}$ production, which was measured at every destructive harvest, cups were inserted in pintsized mason jars and sealed airtight with a lid fitted with a rubber septum. Right after closing the jars, a headspace sample of $30 \mathrm{~mL}$ was taken with a syringe and needle and transferred into pre-evacuated Exetainers. The jars then remained closed for $24 \mathrm{~h}$ before a second sample was taken and transferred to Exetainers. $\mathrm{N}_{2} \mathrm{O}$ concentration in the Exetainers was determined using a Shimadzu GC-2014 equipped 
Table 1. Information on the sites used in the laboratory incubation experiment. MAT is mean annual temperature, MAP is mean annual precipitation, and SOC is soil organic carbon content. Asterisks indicate a significant difference between simple and complex rotations.

\begin{tabular}{|c|c|c|c|c|c|c|c|c|c|}
\hline \multirow[t]{2}{*}{ Site } & \multirow[t]{2}{*}{ Coordinates } & \multirow{2}{*}{$\begin{array}{l}\text { Experiment } \\
\text { established }\end{array}$} & \multirow{2}{*}{$\begin{array}{r}\text { MAT } \\
\left({ }^{\circ}\right)\end{array}$} & \multirow{2}{*}{$\begin{array}{l}\text { MAP } \\
(\mathrm{mm})\end{array}$} & \multirow{2}{*}{$\begin{array}{l}\text { Soil } \\
\text { texture }\end{array}$} & \multicolumn{2}{|c|}{ Plants in rotation } & \multicolumn{2}{|c|}{ SOC $\%$} \\
\hline & & & & & & $\begin{array}{l}\text { Complex } \\
\text { rotation }\end{array}$ & $\begin{array}{l}\text { Simple } \\
\text { rotation }\end{array}$ & $\begin{array}{r}\text { Complex } \\
\text { rotation }\end{array}$ & $\begin{array}{l}\text { Simple } \\
\text { rotation }\end{array}$ \\
\hline $\begin{array}{l}\text { USDA-ARS Akon, } \\
\text { Colorado (CO) }\end{array}$ & $\begin{array}{l}40^{\circ} 07^{\prime} 40^{\prime \prime} \mathrm{N} \\
103^{\circ} 07^{\prime} 58^{\prime \prime} \mathrm{W}\end{array}$ & 1995 & 9.8 & 421 & $\begin{array}{l}\text { Weld silt } \\
\text { loam }\end{array}$ & $\begin{array}{l}\text { Wheat-corn- } \\
\text { millet-pea }\end{array}$ & $\begin{array}{l}\text { Wheat- } \\
\text { millet }\end{array}$ & 0.7 & 0.8 \\
\hline $\begin{array}{l}\text { USDA-ARS } \\
\text { Brookings, } \\
\text { South Dakota (SD) }\end{array}$ & $\begin{array}{l}44^{\circ} 20^{\prime} 27^{\prime \prime} \mathrm{N} \\
96^{\circ} 47^{\prime} 18^{\prime \prime} \mathrm{W}\end{array}$ & 2000 & 6.2 & 580 & $\begin{array}{l}\text { Sandy } \\
\text { clay loam }\end{array}$ & $\begin{array}{l}\text { Corn- } \\
\text { soybean-- } \\
\text { wheat- } \\
\text { sunflower }\end{array}$ & $\begin{array}{l}\text { Corn- } \\
\text { soybean }\end{array}$ & 2.2 & 2.1 \\
\hline $\begin{array}{l}\text { W.K. Kellogg } \\
\text { Biological Station, } \\
\text { Michigan (MI) }\end{array}$ & $\begin{array}{l}42^{\circ} 24^{\prime} 23^{\prime \prime} \mathrm{N} \\
85^{\circ} 22^{\prime} 32^{\prime \prime} \mathrm{W}\end{array}$ & 2000 & 8.9 & 893 & $\begin{array}{l}\text { Loam } \\
\text { and } \\
\text { sandy } \\
\text { loam }\end{array}$ & $\begin{array}{l}\text { Corn- } \\
\text { soybean- } \\
\text { wheat }\end{array}$ & $\begin{array}{l}\text { Corn- } \\
\text { soybean }\end{array}$ & 0.8 & 0.8 \\
\hline $\begin{array}{l}\text { USDA-ARS } \\
\text { Beltsville, } \\
\text { Maryland (MD) }\end{array}$ & $\begin{array}{l}39^{\circ} 01^{\prime} 27^{\prime \prime} \mathrm{N} \\
76^{\circ} 55^{\prime} 29^{\prime \prime} \mathrm{W}\end{array}$ & 1996 & 13.6 & 1192 & Silt loam & $\begin{array}{l}\text { Corn- } \\
\text { soybean- } \\
\text { wheat-alfalfa- } \\
\text { alfalfa-alfalfa }\end{array}$ & $\begin{array}{l}\text { Corn- } \\
\text { soybean }\end{array}$ & $1.3^{*}$ & 1.0 \\
\hline
\end{tabular}

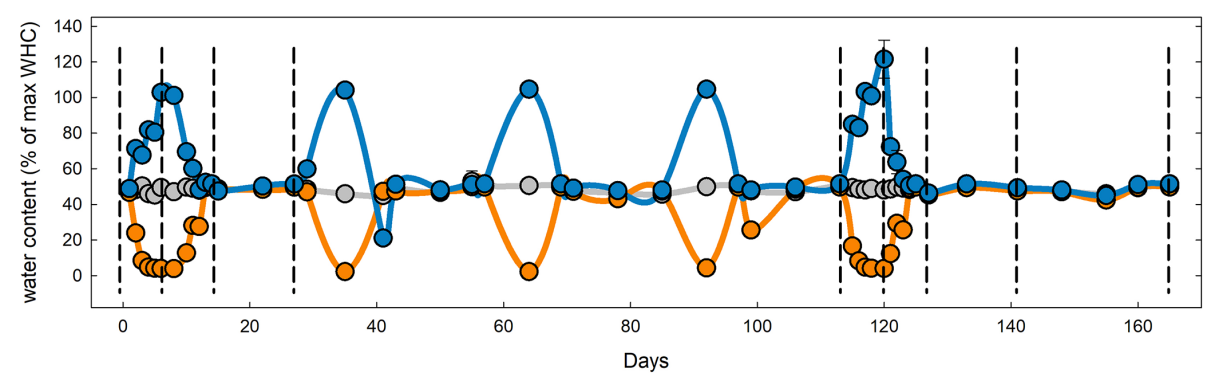

Figure 1. Mean water holding capacity of all four sites and rotation lengths during the course of the experiment. Symbols and lines in blue represent the flooding treatment; orange, the drought treatment; and gray, the control. Dashed vertical lines represent destructive harvests (1-4 and 6-10) of subsets on days $6,14,27,113,120,127,141$, and 165 . To study long-term recovery, an additional set of samples (not shown) underwent only the first stress cycle and was subsequently kept at $50 \%$ WHC until harvest on day 55 (harvest 5 ).

with an ECD detector. $\mathrm{N}_{2} \mathrm{O}$ flux was calculated as the difference in $\mathrm{N}_{2} \mathrm{O}$ concentration between samples collected right after sealing and after $24 \mathrm{~h}$ divided by the time of incubation and the amount of dry soil in the cup and accounting for jar and syringe volume and temperature.

\subsection{Extractable organic carbon (EOC), total extractable nitrogen (TEN), ammonium, nitrate, and microbial biomass carbon (MBC)}

Extractable organic carbon and total extractable nitrogen were measured in $1 \mathrm{M} \mathrm{KCl}$ extracts $(15 \mathrm{~mL})$ from approximately $2 \mathrm{~g}$ of soil using a TOC-L CPH/CPN analyzer (Shimadzu). Ammonium and nitrate concentrations were measured in the same extracts by colorimetric assays as described by Hood-Nowotny et al. (2010). Microbial biomass carbon was determined using chloroform-fumigation extrac- tion (Brookes et al., 1985; Vance et al., 1987). Two grams of fresh soil were fumigated in a desiccator under chloroform atmosphere for $24 \mathrm{~h}$ in the dark and then extracted with $1 \mathrm{M} \mathrm{KCl}$. Extracts of fumigated samples were measured on the TOC-L CPH/CPN analyzer and microbial carbon was calculated as the difference in EOC between the fumigated and the fresh soil extracts. Microbial carbon is presented without the use of a correction factor for extraction efficiency. EOC, TEN, $\mathrm{NH}_{4}, \mathrm{NO}_{3}$, and $\mathrm{MBC}$ were determined at every destructive harvest.

\subsection{Enzyme activities}

Potential extracellular enzyme activities were measured, with adaptations, as described in Schnecker et al. (2015). In short, $2 \mathrm{~g}$ of soil were suspended and homogenized in $100 \mathrm{~mL}$ of $100 \mathrm{mM}$ sodium acetate buffer at $\mathrm{pH}$ 5.5. For 
each sample and each enzyme, five wells of a black microtiter plate were filled with $200 \mu \mathrm{L}$ of the soil slurry. The respective wells were amended substrates labeled with MUF (4-methylumbelliferyl): $\beta$-D-glucopyranoside for $\beta$-glucosidase (BG), $\beta$-D-cellobioside for cellobiohydrolase $(\mathrm{CBH})$, and $\mathrm{N}$-acetyl- $\beta$-D-glucosaminide for $\mathrm{N}$-acetyl-glucosaminidase (NAG). L-Leucine-7-amido-4methyl coumarin was used as substrate for leucine-aminopeptidase (LAP). Plates for the assays of $\mathrm{BG}, \mathrm{CBH}$, NAG, and LAP were incubated for $140 \mathrm{~min}$. Afterwards, activity was measured fluorimetrically (excitation $365 \mathrm{~nm}$ and emission $450 \mathrm{~nm}$ ). Phenoloxidase (POX) and peroxidase (PEX) activities were measured using L-3,4dihydroxyphenylalanine (DOPA) as a substrate in a photometric assay. Three $1 \mathrm{~mL}$ samples of the original soil slurry was mixed with $1 \mathrm{~mL}$ of a $20 \mathrm{mM}$ DOPA solution. After shaking and centrifuging, two wells of each transparent microtiter plate were filled with $250 \mu \mathrm{L}$ of the supernatant. One of these wells additionally received $10 \mu \mathrm{L} \mathrm{H}_{2} \mathrm{O}_{2}(0.3 \%)$ for determination of peroxidase activity. Plates for oxidative enzyme activities were measured photometrically (absorbance $450 \mathrm{~nm}$ ) at the beginning and after incubation for $20 \mathrm{~h}$. PEX activity was calculated as the difference in the increase in color during the incubation time between the wells with and without $\mathrm{H}_{2} \mathrm{O}_{2}$ addition. All other enzyme activities were calculated as the increase in color or fluorescence during the incubation time. Potential enzyme activities were determined at every destructive harvest.

\subsection{Labile carbon}

To quantify labile soil carbon we used the permanganate oxidizable carbon (POXC) method (Weil et al., 2003) as described in Culman et al. (2012). In short, $2.5 \mathrm{~g}$ of air-dried soil were mixed with $18 \mathrm{~mL}$ of deionized water and $2 \mathrm{~mL}$ of $0.2 \mathrm{M} \mathrm{KMnO}_{4}$ stock solution and shaken for 2 min at 240 oscillations per minute on an oscillating shaker. Tubes were removed from the shaker and allowed to settle for $10 \mathrm{~min}$. After $10 \mathrm{~min}, 0.5 \mathrm{~mL}$ of the supernatant was mixed with $49.5 \mathrm{~mL}$ of deionized water. An aliquot $(200 \mu \mathrm{L})$ of each sample was loaded into a 96-well plate containing a set of internal standards, a soil standard, and a solution standard (laboratory reference samples). Sample absorbance was read with a spectrometer at $550 \mathrm{~nm}$. POXC was determined at every destructive harvest for Colorado and Maryland soils.

\subsection{Statistics}

To evaluate the effect of the specific stress treatments, we calculated response ratios of all variables measured during destructive harvests as the values for the treated samples divided by the values for the control samples under constant water conditions. To evaluate differences between the control and treatment samples, we performed two-sample comparison tests $(t$-test, Welch's $t$-test or Mann-Whitney $U$ test as appropriate for each variable's normality and homogeneity of variance). We further used all data measured at destructive harvests, with the exception of water content, individually for each harvest date and including all water treatments at peak stress and right after the stress during the first and last stress cycles (days 6, 14, 120, and 127) in principal components analysis (PCA). We used one-way ANOVA and Tukey HSD as a post hoc test on the first two axes of the PCAs to evaluate differences among water treatments, crop rotation complexity treatments, and their interaction. Before analysis, data were log-transformed or rank-normalized to meet the assumptions for ANOVA. Differences and correlations were assumed to be significant at $p<0.05$. Statistics were performed in R 3.3.2 (R Development Core Team, 2013).

\section{Results}

\subsection{Differences among sites and rotations}

The sites used in this study represent a gradient in MAP from an arid system in Colorado (MAP $421 \mathrm{~mm}$ ) to a site with relatively high MAP in Maryland $(1192 \mathrm{~mm})$, with South Dakota $(580 \mathrm{~mm})$ and Michigan $(892 \mathrm{~mm})$ providing intermediate MAP. Soil organic carbon (SOC) content varied greatly between sites, being highest in South Dakota, followed by Maryland, Colorado, and Michigan (Table 1). Significant differences in SOC content between rotation lengths could only be found in Maryland where soils from the complex rotation had an average of $1.3 \%$ OC and soils from the simple rotation length had $1.0 \%$ OC; notably, this was also the only site that included a perennial crop in the complex rotation.

\subsection{Heterotrophic respiration response to drought and flooding}

Respiration decreased significantly in response to drought in soils from all sites and crop rotation complexities and returned to control levels as soon as microcosms were returned to $50 \%$ WHC after the first (day 1-15) and fifth (day 113127) stress cycle (Fig. 2). In some cases (Maryland first and fifth stress, South Dakota fifth stress, and Michigan fifth stress) respiration in rewetted microcosms exceeded respiration in control microcosms. Soils from simple and complex rotations did not differ in the response to drought, but in some cases differed in their recovery from the stress, most notably in soils from Maryland and South Dakota where soils from simple rotations showed lower respiration rates. In general, soils experienced slight but mostly not significant increases in respiration in response to flooding. In the Colorado simple rotation, the Maryland simple rotation, the Michigan complex rotation, and both South Dakota rotations, flooding significantly increased respiration only on day 4 and thereafter was indistinguishable from the control until the end of the first stress. Soils from the complex rotation in South Dakota 


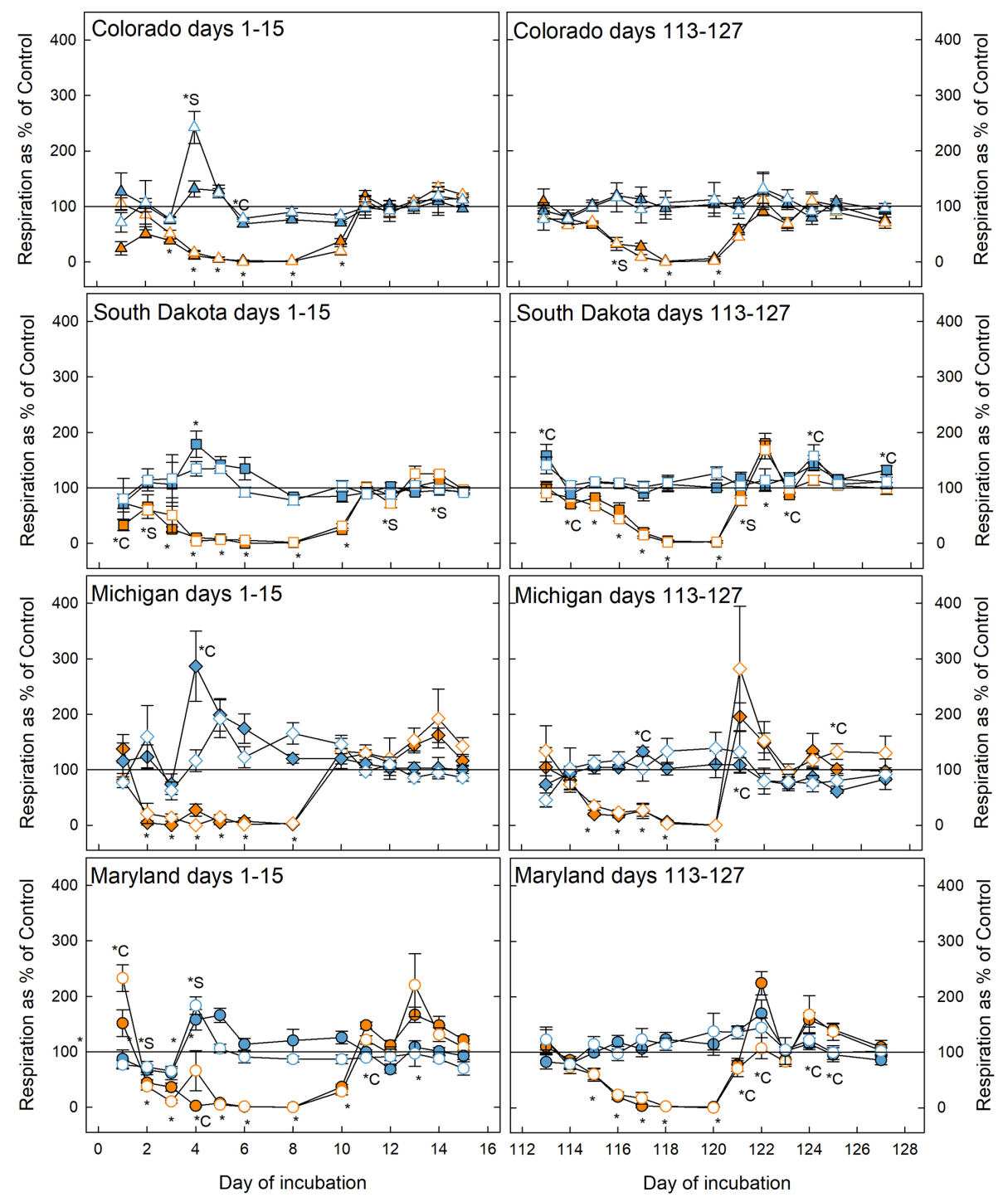

Figure 2. Soil respiration rates during the first (left panels) and fifth (right panels) stress cycles relative to the control at $50 \%$ WHC. Blue symbols represent microcosms exposed to flooding and orange symbols represent drought treatment. Open symbols are simple rotations and filled symbols are the complex rotations at the respective sites. The * symbol indicates that the treatment significantly changed respiration with respect to the control; ${ }^{*} \mathrm{C}$ and ${ }^{*} \mathrm{~S}$ mean that only soil samples from complex or simple rotations, respectively, had significantly different respiration rates than the respective control. If indicators for significance are above the graphs, they refer to the flooding treatment; below, they refer to the drought treatment. Significant difference was assumed at $p<0.05$.

further showed an increase in respiration during the recovery from flooding after the fifth stress.

\subsection{Cumulative respiration}

We measured cumulative respiration to estimate soil carbon loss. Respiration was highest in soils from Colorado, followed by those from Maryland, Michigan, and South Dakota (Fig. 3). During the first stress cycle, soils from all sites lost significantly less $\mathrm{CO}_{2}$ under drought compared to control and flooding treatments (Fig. 3b), but $\mathrm{CO}_{2}$ did not differ between flooded and control soils at any site for a given rotation treat- ment. During the fifth stress cycle, $\mathrm{CO}_{2}$ losses were significantly lower with drought compared to control and flooding in soils from Colorado and South Dakota under both rotation regimes, and drought-stressed soils from the Maryland complex rotation lost significantly less $\mathrm{CO}_{2}$ than flooded microcosms. Total loss of carbon as $\mathrm{CO}_{2}$ (calculated per gram of $\mathrm{SOC}$ ) over the entire incubation period tended to be lower in microcosms experiencing repeated drought compared to the control and flooded microcosms (Fig. 3a). However, droughtstressed soils under complex rotation in Colorado lost significantly less carbon as $\mathrm{CO}_{2}$ than the control and flooded soils, and soils from simple rotations in South Dakota lost more 


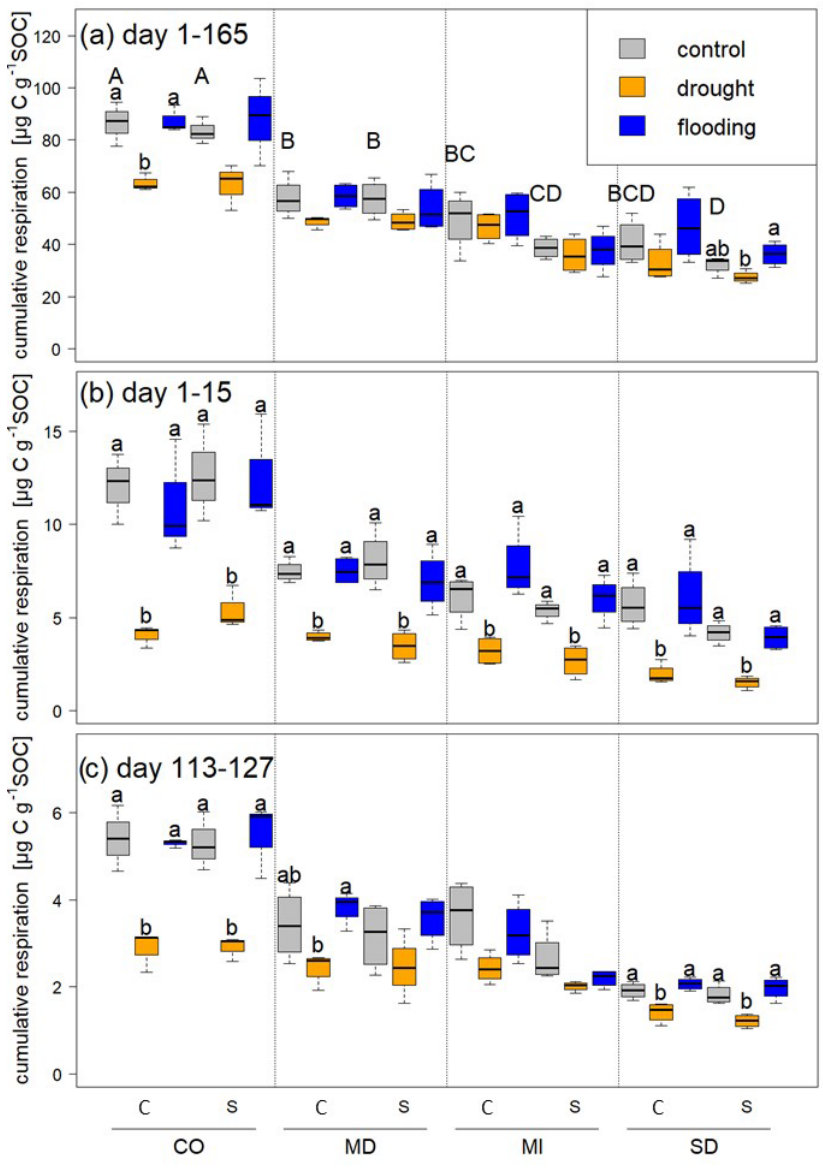

Figure 3. Cumulative respiration calculated per gram of SOC over (a) the whole experimental period, (b) during the first stress period, and (c) during the fifth stress period. Statistically significant differences among control, drought, and flooding treatments for a given site and rotation complexity $(\mathrm{C}$ is a complex rotation and $\mathrm{S}$ is a simple rotation) are indicated by letters. Capital letters indicate differences among control treatments of all sites and rotations.

carbon when flooded compared to drought; control soils were not significantly different with either stress treatment.

\subsection{Effect of drought and flooding on soil carbon and nitrogen pools and microbial functions in the driest (CO) and wettest (MD) locations}

Flooding and drought caused significant changes in soil nitrogen and carbon pools, microbial biomass, microbial enzyme activities, and nitrous oxide production. Except for experimentally manipulated water content and a decrease in respiration during drought, no variables changed consistently and significantly among soils from Colorado and Maryland (Tables 3 and 4). In general, drought tended to decrease measured parameters, while flooding increased them. Microbial biomass carbon increased during the first flooding event in soils from complex rotations in Maryland and strongly de- creased during the fifth drought cycle in all Maryland soils. Microbial biomass in soils from Colorado was not affected by the treatments. In Colorado, all enzyme activities decreased with drought while NAG alone increased with flooding. This was not the case in Maryland soils, where enzyme activities remained constant through water stress or changed only after the stress was over. Only a few parameters changed similarly during the first and fifth stress periods. LAP decreased during the first and fifth drought stresses in the simple Colorado rotation treatment. Production of $\mathrm{N}_{2} \mathrm{O}$ increased in response to the first and fifth flooding in the Maryland complex rotation soil; in this rotation treatment NAG decreased after both the first and fifth drought. All other parameters affected by the stress treatment changed only during either the first or fifth stress in single site-rotation combinations at peak stress or following the stress.

\subsection{Recovery from stress}

Principal component analyses caused samples from flooding and drought treatment to cluster in to separate groups (PCAs; Fig. 4). Samples clustered similarly and treatment differences on individual PCA axes were significant (Table 2) during the first (Fig. 4) and fifth stress (Fig. 5). In both cases these differences were no longer significant after the end of drought and flooding, when microcosms returned to $50 \%$ WHC (Figs. 4 and 5; Table 2). In the case of the Maryland samples, significant differences could be found between simple and complex rotations during and after the first and fifth stress periods. Differences between rotations in Colorado were only found after the fifth stress period.

\section{Discussion}

Drought and flooding represent severe stressors for soil microbial communities. In our study of soils under low- and high-diversity crop rotation regimes from agricultural sites across the U.S., we found that short-term drought - and to a lesser degree, flooding - led to overall significant and stressspecific changes in microbial processes and functions. Respiration was strongly reduced in all sites and rotation treatments during drought stress. Flooding caused $\mathrm{N}_{2} \mathrm{O}$ production in soils from three of four sites during the first flooding event, though this effect remained after the fifth flooding only in soils from Maryland. We found potential sitedependent legacy effects for $\mathrm{CO}_{2}$ release at the drier Colorado site where we found the highest specific cumulative respiration rates of all sites (Fig. 3) and a consistent lack of the Birch effect (Birch, 1958). Interestingly, soils managed under rotations of only two crops versus three or four did not significantly differ in their response to stress. In general, all soils - irrespective of site and rotational complexity - responded strongly to drought and flooding but recovered quickly to control levels when water content returned to $50 \%$ 

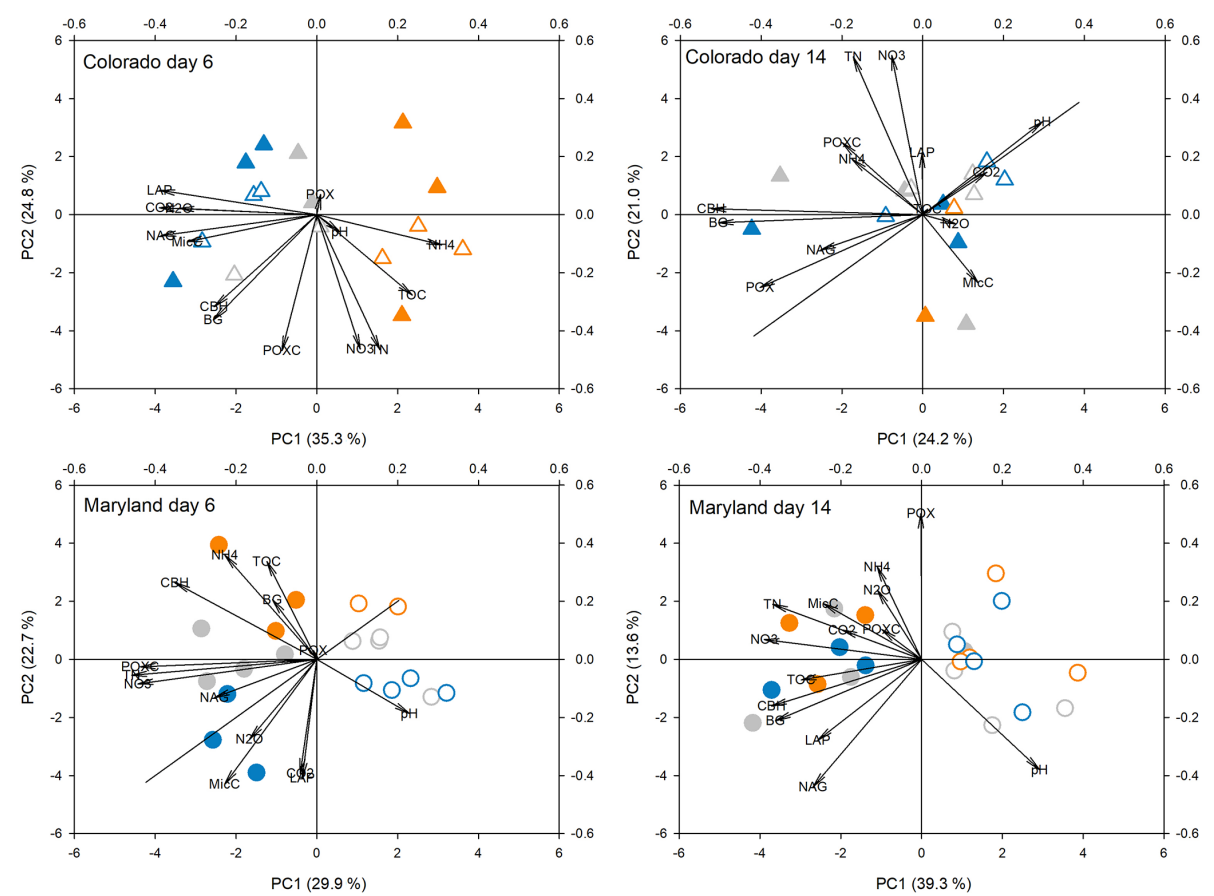

Figure 4. Principal components analysis of all response parameters at first peak stress (day 6) and following the first stress (day 14) in soils from Colorado and Maryland. Blue symbols are the flooding treatment and orange symbols are the drought treatment. Gray symbols are the control. Open symbols represent simple and filled symbols represent complex rotations. Significant differences between treatments along the axes are shown in Table 2. Included parameters are $\mathrm{pH}$, extractable organic carbon (EOC), total extractable nitrogen (TEN), microbial biomass carbon (MBC), $\mathrm{NH}_{4}, \mathrm{NO}_{3}$, activities of $\beta$-glucosidase (BG), cellobiohydrolase (CBH), N-acetyl-glucosaminidase (NAG), leucine-aminopeptidase (LAP), phenoloxidase (POX) and peroxidase (PEX), respiration $\left(\mathrm{CO}_{2}\right), \mathrm{N}_{2} \mathrm{O}$ production $\left(\mathrm{N}_{2} \mathrm{O}\right)$, and permanganate oxidizable carbon $(\mathrm{POXC})$.

Table 2. Results from analysis of variance of treatments on axis from PCAs as seen in Figs. 4 and 5. Bold values represent significant differences between treatments (drought, flooding, and control).

\begin{tabular}{|c|c|c|c|c|c|c|c|c|c|c|c|c|}
\hline & \multicolumn{6}{|c|}{ PC1 } & \multicolumn{6}{|c|}{ PC2 } \\
\hline & \multicolumn{2}{|c|}{ Treatment } & \multicolumn{2}{|c|}{ Rotation } & \multicolumn{2}{|c|}{ Interaction } & \multicolumn{2}{|c|}{ Treatment } & \multicolumn{2}{|c|}{ Rotation } & \multicolumn{2}{|c|}{ Interaction } \\
\hline & $F$ & $p$ & $F$ & $p$ & $F$ & $p$ & $F$ & $p$ & $F$ & $p \mid$ & $F$ & $p$ \\
\hline Colorado day 14 recovery & 0.047 & 0.954 & 2.054 & 0.190 & 0.055 & 0.947 & 1.296 & 0.325 & 4.627 & 0.064 & 0.461 & 0.646 \\
\hline Colorado day 120 peak stress & 3.214 & 0.076 & 0.431 & 0.524 & 0.109 & 0.898 & 4.124 & 0.043 & 5.291 & 0.040 & 0.813 & 0.466 \\
\hline Colorado day 127 recovery & 0.795 & 0.476 & 2.107 & 0.175 & 0.017 & 0.983 & 0.496 & 0.622 & 4.416 & 0.060 & 0.553 & 0.591 \\
\hline Maryland day 120 peak stress & 6.872 & 0.007 & 47.63 & $<0.001$ & 0.979 & 0.397 & 80.916 & $<0.001$ & 22.038 & $<0.001$ & 1.945 & 0.175 \\
\hline Maryland day 121 recovery & 0.622 & 0.548 & 89.13 & $<0.001$ & 2.043 & 0.159 & 0.583 & 0.568 & 0.025 & 0.876 & 0.470 & 0.632 \\
\hline
\end{tabular}

of WHC, suggesting that the investigated agricultural soils microbial communities are highly resilient to water stress.

\subsection{Response to water stress}

All soils had significantly decreased respiration rates in response to drought during the first stress cycle with the strongest relative decreases at the Colorado site. Compared to drought, flooding had a smaller effect on microbial res- piration. In general, flooding slightly increased respiration rates, but this was only significant during the first stress cycle for 1 to $2 \mathrm{~d}$ and was not consistent across rotation treatments. Flooding may increase respiration rates in part due to increased connectivity and availability of previously untapped DOC sources to microorganisms (Schimel, 2018 and therein). Cumulative carbon losses were significantly different among sites. Surprisingly, despite having the highest SOC contents, soils from South Dakota lost the least 

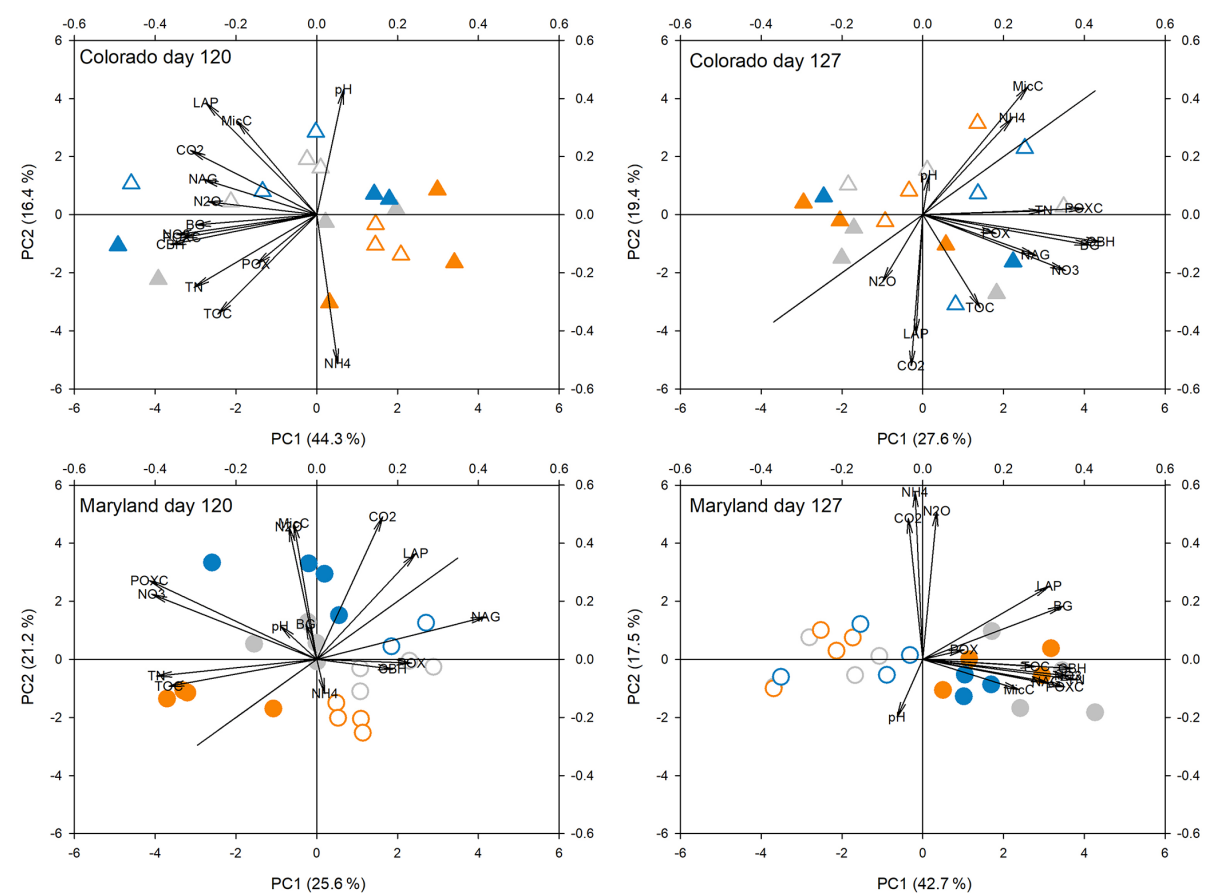

Figure 5. Principal components analysis of all response parameters at the fifth peak stress (day 120) and following the fifth stress (day 127) in soils from Colorado and Maryland. Blue symbols are the flooding treatment and orange symbols are the drought treatment. Gray symbols are the control. Open symbols represent simple and filled symbols represent complex rotations. Significant differences between treatments along the axes are shown in Table 2. Included parameters are $\mathrm{pH}$, extractable organic carbon (EOC), total extractable nitrogen (TEN), microbial biomass carbon (MBC), $\mathrm{NH}_{4}, \mathrm{NO}_{3}$, activities of $\beta$-glucosidase (BG), cellobiohydrolase (CBH), $\mathrm{N}$-acetyl-glucosaminidase (NAG), leucine-amino-peptidase (LAP), phenoloxidase (POX) and peroxidase (PEX), respiration $\left(\mathrm{CO}_{2}\right), \mathrm{N}_{2} \mathrm{O}$ production $\left(\mathrm{N}_{2} \mathrm{O}\right)$, and permanganate oxidizable carbon (POXC).

carbon as $\mathrm{CO}_{2}$ over the whole incubation period. Differences in cumulative respiration between sites could be related to differences in mineralogy and soil texture (Saidy et al., 2015; Schmidt et al., 2011), microbial community composition (Babin et al., 2013), or the chemistry of plant and fertilizer inputs (McDaniel and Grandy, 2016). Our data hint at physical soil properties as potentially relevant factors for SOC stabilization and susceptibility to water stress as our four sites not only represent a precipitation gradient but also a gradient in texture, which is reflected to some extent in SOC contents but less so in the observed cumulative carbon loss.

Aside from $\mathrm{CO}_{2}$ production during drought, no factor investigated in the two soils from climate extremes (Colorado and Maryland) changed consistently in response to drought and flooding (Table 3). Microbial biomass was affected during the first flooding cycle and fifth drought cycle in Maryland soils but not in soils from Colorado. In Colorado, for soils of both rotation lengths, LAP decreased with drought, which was not the case in soils from Maryland. All flooded Colorado soils produced $\mathrm{N}_{2} \mathrm{O}$, while this was only the case in the complex rotation in Maryland. Beside these site-specific effects, we could not find drought or flooding effects that occurred in either rotation treatment at both sites. Extracellular enzyme activities in particular remained relatively unaf- fected by the applied stresses. A reason for this might be the stabilization of enzymes on soil minerals, which might protect them against drought and flooding (Allison and Jastrow, 2006; Kramer et al., 2013). This stabilization might also explain why our findings are in contrast to results from temperature stress experiments in plant litter (Mooshammer et al., 2017).

However, when soil samples were ordinated in response parameter space in a PCA, a clear stress treatment effect emerged in Colorado and Maryland soils irrespective of the rotation treatment (Tables 2, 3, and 4). Maryland but not Colorado soils showed an additional rotation effect: samples from simple and complex rotations at this site separated in the PCA, both during and after drought and flooding events. This was most likely related to higher SOC content and covarying soil properties in the complex crop rotation soils, which we found only in Maryland. The experimental field in Maryland had the most complex crop rotation (four crops) and was the only site where the complex rotation included a perennial crop and fertilization with poultry litter, both effective methods for increasing soil carbon stocks and soil health (Ashworth et al., 2018; King and Blesh, 2018). The introduction of cover crops might be more effective than increasing cropping diversity alone (McDaniel et al., 2014). 
Table 3. Mean response ratios of soil carbon and nitrogen pools, microbial enzyme activities, and $\mathrm{CO}_{2}$ and $\mathrm{N}_{2} \mathrm{O}$ production in response to drought and flooding during (day 6), immediately after (day 14), 2 weeks (day 27) after, and 6 weeks (day 55) after the first stress cycle. Orange colors indicate a reduction relative to the control and green colors represent an increase. Only significant differences $(p<0.05)$ are shown. Response ratios are calculated as the value for a given treatment divided by the value of the respective control at $50 \% \mathrm{WHC}$. C is a complex rotation, $\mathrm{S}$ is a simple rotation, and POXC is permanganate oxidizable carbon.
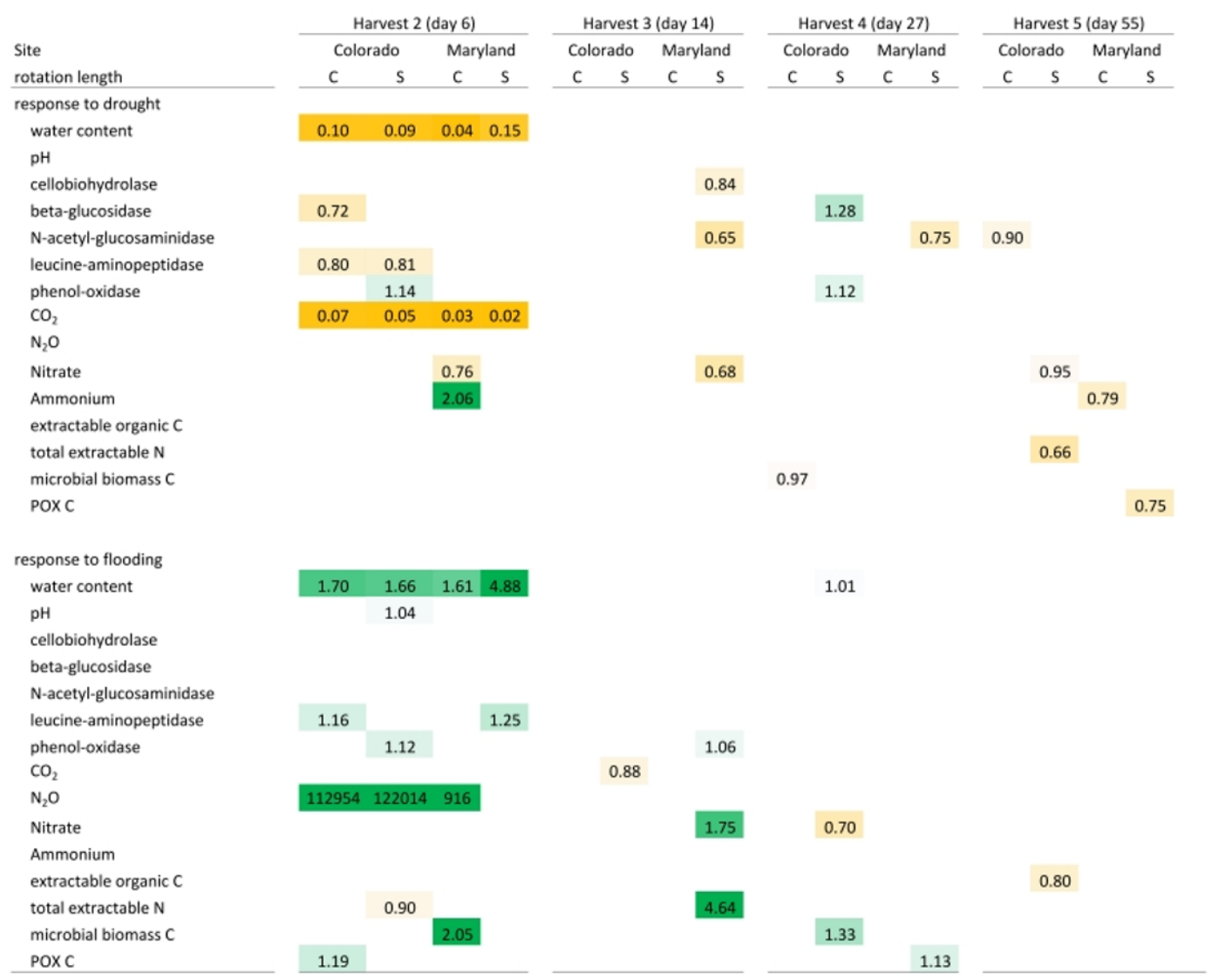

One reason for the apparently mild reaction to drought and flooding in this experiment might be the duration of the stress we applied. Stress slowly applied over several days and lasting less than 2 weeks in total might be similar to conditions that microorganisms in the investigated soils experience frequently in the field. Stress effects have indeed been found to strongly vary with the duration of stress as well as its intensity (Tiemann and Billings, 2011, 2012).

\subsection{Recovery from stress}

In our experiment, only soils from Maryland showed a stressinduced increase in respiration during recovery compared to unstressed control soils; specifically, respiration increased in soils from the complex Maryland rotation in the first day following stress and in the simple rotation after $3 \mathrm{~d}$. The lack of a Birch effect in all other soils might be because we rewetted the soil in small increments over the course of $3 \mathrm{~d}$ rather than a flush rewetting, which often results in a large increase in respiration (Birch, 1958; Göransson et al., 2013). It might also be the case that the duration of desiccation was too short to lead to a pronounced $\mathrm{CO}_{2}$ pulse at rewetting (Unger et al., 2010).

Like respiration rates, most other measured parameters returned to control levels following stress; this was also apparent in the PCA where dried and flooded soils were indistinguishable from control soils at a constant water content of $50 \%$ WHC. This indicates that while all soils were significantly affected by the stress treatment, they are highly resilient and recovered quickly from stress. This is in accordance with Kaurin et al. (2018) who found that microbial communities in agricultural soils recovered after rewetting even after severe and prolonged drought periods and Barnard et al. (2013) who found similarly quick recovery of the soil microbial community after rewetting of dry grassland soils.

\subsection{Adaptation to stress}

As during the first stress period, respiration rates declined in soils from all sites and rotations during the fifth drought cy- 
Table 4. Mean response ratios of soil carbon and nitrogen pools, microbial enzyme activities, and $\mathrm{CO}_{2}$ and $\mathrm{N}_{2} \mathrm{O}$ production in response to drought and flooding before (day 113), during (day 120), immediately after (day 127), 2 weeks (day 141) after, and 6 weeks (day 165) after the fifth stress cycle. Orange colors indicate a reduction relative to the control and green colors represent an increase. Only significant differences $(p<0.05)$ are shown. Response ratios are calculated as the value for a given treatment divided by the value of the respective control at $50 \%$ WHC. C is a complex rotation, $\mathrm{S}$ is a simple rotation, and POXC is permanganate oxidizable carbon.

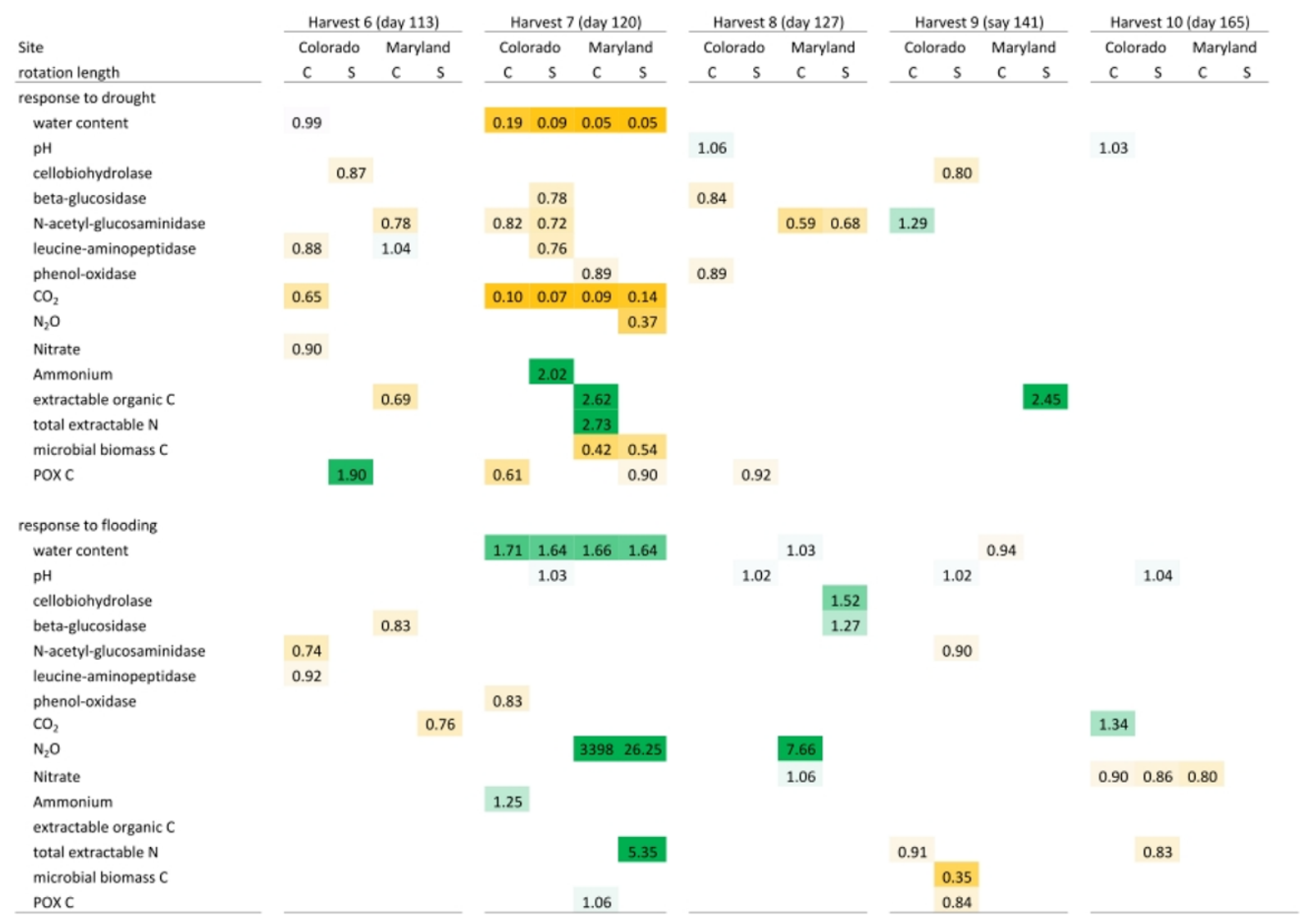

cle. In contrast, respiration was unaffected by flooding, with the exception of a slight increase in the Michigan complex rotation $5 \mathrm{~d}$ after flooding. After the end of the fifth drought cycle, in contrast to the first cycle, we found clear increases in respiration when soils from Maryland, South Dakota, and Michigan returned to $50 \%$ WHC. Both observations might be related to the absence of plant inputs in our incubation experiment. Plants have been shown to strongly respond to drought (Fuchslueger et al., 2014; Kaisermann et al., 2017), but will provide some amount of carbon even if rhizodeposition is reduced under drought (Canarini and Dijkstra, 2015). During the vegetation period, such a continuous supply of root exudates might prevent an increase in respiration at the end of a stress event when connectivity between microbes and substrate is re-established, such as our observation after the fifth but not the first stress. Management practices that extend the vegetation period and minimize fallow periods might help maintain a constant supply of DOC to soil microorganisms and thereby buffer their response to drought and flooding.
We also found site-specific differences between the first and the fifth stress cycles. In soils from Colorado from both rotation regimes, NAG was significantly reduced in the drought treatment compared to the control. In contrast, drought reduced total extractable nitrogen in Maryland soils while flooding released $\mathrm{N}_{2} \mathrm{O}$ in both Maryland rotations. In Colorado soils no $\mathrm{N}_{2} \mathrm{O}$ production could be detected by the fifth stress cycle. This might have been caused by a depletion of the dissolved substrate for $\mathrm{N}_{2} \mathrm{O}$ production or could be related to plant-induced differences in microbial community composition (Hammerl et al., 2019) that had faded after $160 \mathrm{~d}$ of incubation.

The lack of microbial adaptation to the re-occurring stress in all except the Colorado soils might be interpreted as an already existing adaptation to conditions mimicked in our experiment or could again be ascribed to the modest stress events of our lab experiment compared to the larger environmental fluctuations these soils experienced in situ. 


\subsection{Summary}

In this study we found that drought - and, to a lesser extent, short-term flooding - significantly affected respiration rates at all sites and at some sites had additional effects on some microbial enzyme activities, soil carbon and nitrogen pools, and nitrous oxide emissions. Furthermore, an increase in crop rotational diversity did not lead to generally different responses of soils to short-term drought and flooding, even at the one site where increased crop rotation complexity also caused an increase in SOC. While soil function reacted significantly during stress events, all soils recovered quickly and returned to control levels once the stress ended. This indicates that soil microbial processes in these agricultural soils collected from variable climate regions within the United States are highly resilient to short-term drought and flooding. Future experiments should also include plants as they are an important component of agroecosystems in the field and could strongly influence DOC and DON availability. Our laboratory study focused on the soil-microbe system and showed that, at least in the absence of plants, microbial functions and activities are highly resilient to drought and flooding and recover quickly from stress.

Data availability. The data produced in this study are available through Phaidra (https://doi.org/11353/10.1220845, https://doi.org/11353/10.1220844, Schnecker, 2021a, b). The data may also be requested by email from the corresponding author.

Supplement. The supplement related to this article is available online at: https://doi.org/10.5194/soil-7-547-2021-supplement.

Author contributions. JS and ASG conceived the experiment. FC, MC, RML, LKT provided soil samples. JS and DBM processed and analyzed the soil samples. JS analyzed and interpreted the data and wrote the manuscript. All authors contributed to the data interpretation and provided essential comments to the manuscript.

Competing interests. The authors declare that they have no conflict of interest.

Disclaimer. Publisher's note: Copernicus Publications remains neutral with regard to jurisdictional claims in published maps and institutional affiliations.

Acknowledgements. This research used samples and data from the Long-Term Agroecosystem Research (LTAR) network, which is supported by the United States Department of Agriculture. The Michigan and Maryland soils used in the study are from LTAR sites. Long-term crop rotation treatments at the South Dakota site are managed and maintained by Shannon Osborne, USDA-ARS.
This research was funded by the National Institute of Food and Agriculture, U.S. Department of Agriculture, under award number 2014-67019-21716.

Financial support. This research has been supported by the National Institute of Food and Agriculture (grant no. 2014-6701921716).

Review statement. This paper was edited by Ember Morrissey and reviewed by Elizabeth Bach and Theresa McHugh.

\section{References}

Allison, S. D. and Jastrow, J. D.: Activities of extracellular enzymes in physically isolated fractions of restored grassland soils, Soil Biol. Biochem., 38, 3245-3256, https://doi.org/10.1016/j.soilbio.2006.04.011, 2006.

Allison, S. D. and Martiny, J. B. H.: Resistance, resilience, and redundancy in microbial communities, P. Natl. Acad. Sci. USA, 105, 11512-11519, https://doi.org/10.1073/pnas.0801925105, 2008.

Ashworth, A. J., Allen, F. L., DeBruyn, J. M., Owens, P. R., and Sams, C.: Crop Rotations and Poultry Litter Affect Dynamic Soil Chemical Properties and Soil Biota Long Term, J. Environ. Qual., 47, 1327-1338, https://doi.org/10.2134/jeq2017.12.0465, 2018.

Babin, D., Ding, G.-C., Pronk, G. J., Heister, K., Kögel-Knabner, I., and Smalla, K.: Metal oxides, clay minerals and charcoal determine the composition of microbial communities in matured artificial soils and their response to phenanthrene, FEMS Microbiol. Ecol., 86, 3-14, https://doi.org/10.1111/1574-6941.12058, 2013.

Bailey, V. L., Smith, A. P., Tfaily, M., Fansler, S. J., and Bond-Lamberty, B.: Differences in soluble organic carbon chemistry in pore waters sampled from different pore size domains, Soil Biol. Biochem., 107, 133-143, https://doi.org/10.1016/j.soilbio.2016.11.025, 2017.

Barnard, R. L., Osborne, C. A., and Firestone, M. K.: Responses of soil bacterial and fungal communities to extreme desiccation and rewetting, ISME J., 7, 2229-2241, https://doi.org/10.1038/ismej.2013.104, 2013.

Berglund, Ö. and Berglund, K.: Influence of water table level and soil properties on emissions of greenhouse gases from cultivated peat soil, Soil Biol. Biochem., 43, 923-931, https://doi.org/10.1016/j.soilbio.2011.01.002, 2011.

Birch, H. F.: The effect of soil drying on humus decomposition and nitrogen availability, Plant Soil, 10, 9-31, https://doi.org/10.1007/BF01343734, 1958.

Bowles, T. M., Atallah, S. S., Campbell, E. E., Gaudin, A. C. M., Wieder, W. R., and Grandy, A. S.: Addressing agricultural nitrogen losses in a changing climate, Nat. Sustain., 1, 399-408, https://doi.org/10.1038/s41893-018-0106-0, 2018.

Bowles, T. M., Mooshammer, M., Socolar, Y., Calderón, F., Cavigelli, M. A., Culman, S. W., Deen, W., Drury, C. F., Garcia y Garcia, A., Gaudin, A. C. M., Harkcom, W. S., Lehman, R. M., Osborne, S. L., Robertson, G. P., Salerno, J., Schmer, M. R., 
Strock, J., and Grandy, A. S.: Long-Term Evidence Shows that Crop-Rotation Diversification Increases Agricultural Resilience to Adverse Growing Conditions in North America, One Earth, 2, 284-293, https://doi.org/10.1016/j.oneear.2020.02.007, 2020.

Brookes, P. C., Landman, A., Pruden, G., and Jenkinson, D. S.: Chloroform fumigation and the release of soil nitrogen: A rapid direct extraction method to measure microbial biomass nitrogen in soil, Soil Biol. Biochem., 17, 837-842, https://doi.org/10.1016/0038-0717(85)90144-0, 1985.

Calderón, F. J. and Jackson, L. E.: Rototillage, Disking, and Subsequent Irrigation, J. Environ. Qual., 31, 752-758, https://doi.org/10.2134/jeq2002.7520, 2002.

Canarini, A. and Dijkstra, F. A.: Dry-rewetting cycles regulate wheat carbon rhizodeposition, stabilization and nitrogen cycling, Soil Biol. Biochem., 81, 195-203, https://doi.org/10.1016/j.soilbio.2014.11.014, 2015.

Cavigelli, M. A., Teasdale, J. R., and Conklin, A. E.: Long-Term Agronomic Performance of Organic and Conventional Field Crops in the Mid-Atlantic Region, Agron. J., 100, 785-794, https://doi.org/10.2134/agronj2006.0373, 2008.

Culman, S. W., Snapp, S. S., Freeman, M. A., Schipanski, M. E., Beniston, J., Lal, R., Drinkwater, L. E., Franzluebbers, A. J., Glover, J. D., Grandy, A. S., Lee, J., Six, J., Maul, J. E., Mirksy, S. B., Spargo, J. T., and Wander, M. M.: Permanganate Oxidizable Carbon Reflects a Processed Soil Fraction that is Sensitive to Management, Soil Sci. Soc. Am. J., 76, 494-504, https://doi.org/10.2136/sssaj2011.0286, 2012.

Davidson, E. A.: Sources of Nitric Oxide and Nitrous Oxide following Wetting of Dry Soil, Soil Sci. Soc. Am. J., 56, 95-102, https://doi.org/10.2136/sssaj1992.03615995005600010015x, 1992.

DeAngelis, K. M., Silver, W. L., Thompson, A. W., and Firestone, M. K.: Microbial communities acclimate to recurring changes in soil redox potential status, Environ. Microbiol., 12, 3137-3149, https://doi.org/10.1111/j.1462-2920.2010.02286.x, 2010.

Ding, G., Liu, X., Herbert, S., Novak, J., Amarasiriwardena, D., and Xing, B.: Effect of cover crop management on soil organic matter, Geoderma, 130, 229-239, https://doi.org/10.1016/j.geoderma.2005.01.019, 2006.

Evans, S. E. and Wallenstein, M. D.: Soil microbial community response to drying and rewetting stress: Does historical precipitation regime matter?, Biogeochemistry, 109, 101-116, https://doi.org/10.1007/s10533-011-9638-3, 2012.

Fierer, N. and Schimel, J. P.: Effects of drying-rewetting frequency on soil carbon and nitrogen transformations, Soil Biol. Biochem., 34, 777-787, https://doi.org/10.1016/S0038-0717(02)00007-X, 2002.

Fuchslueger, L., Bahn, M., Fritz, K., Hasibeder, R., and Richter, A.: Experimental drought reduces the transfer of recently fixed plant carbon to soil microbes and alters the bacterial community composition in a mountain meadow, New Phytol., 201, 916-927, https://doi.org/10.1111/nph.12569, 2014.

Girvan, M. S., Campbell, C. D., Killham, K., Prosser, J. I., and Glover, L. A.: Bacterial diversity promotes community stability and functional resilience after perturbation, Environ. Microbiol., 7, 301-313, https://doi.org/10.1111/j.1462-2920.2005.00695.x, 2005.

Göransson, H., Godbold, D. L., Jones, D. L., and Rousk, J.: Bacterial growth and respiration responses upon rewetting dry forest soils: Impact of drought-legacy, Soil Biol. Biochem., 57, 477486, https://doi.org/10.1016/j.soilbio.2012.08.031, 2013.

Grandy, A. S. and Robertson, G. P.: Land-use intensity effects on soil organic carbon accumulation rates and mechanisms, Ecosystems, 10, 58-73, https://doi.org/10.1007/s10021006-9010-y, 2007.

Griffiths, B. S. and Philippot, L.: Insights into the resistance and resilience of the soil microbial community, FEMS Microbiol. Rev., 37, 112-129, https://doi.org/10.1111/j.1574-6976.2012.00343.x, 2013.

Hammerl, V., Kastl, E. M., Schloter, M., Kublik, S., Schmidt, H., Welzl, G., Jentsch, A., Beierkuhnlein, C., and Gschwendtner, S.: Influence of rewetting on microbial communities involved in nitrification and denitrification in a grassland soil after a prolonged drought period, Sci. Rep.-UK, 9, 1-10, https://doi.org/10.1038/s41598-018-38147-5, 2019.

Herron, P. M., Stark, J. M., Holt, C., Hooker, T., and Cardon, Z. G.: Microbial growth efficiencies across a soil moisture gradient assessed using ${ }^{13} \mathrm{C}$-acetic acid vapor and $15 \mathrm{~N}$-ammonia gas, Soil Biol. Biochem., 41, 1262-1269, https://doi.org/10.1016/j.soilbio.2009.03.010, 2009.

Hood-Nowotny, R., Umana, N. H.-N., Inselbacher, E., OswaldLachouani, P., and Wanek, W.: Alternative Methods for Measuring Inorganic, Organic, and Total Dissolved Nitrogen in Soil, Soil Sci. Soc. Am. J., 74, 1018-1027, https://doi.org/10.2136/sssaj2009.0389, 2010.

Jackson, L. E., Calderon, F. J., Steenwerth, K. L., Scow, K. M., and Rolston, D. E.: Responses of soil microbial processes and community structure to tillage events and implications for soil quality, Geoderma, 114, 305-317, https://doi.org/10.1016/S00167061(03)00046-6, 2003.

Kaisermann, A., de Vries, F. T., Griffiths, R. I., and Bardgett, R. D.: Legacy effects of drought on plant-soil feedbacks and plant-plant interactions, New Phytol., 215, 1413-1424, https://doi.org/10.1111/nph.14661, 2017.

Kaurin, A., Mihelič, R., Kastelec, D., Grčman, H., Bru, D., Philippot, L., and Suhadolc, M.: Resilience of bacteria, archaea, fungi and $\mathrm{N}$-cycling microbial guilds under plough and conservation tillage, to agricultural drought, Soil Biol. Biochem., 120, 233245, https://doi.org/10.1016/j.soilbio.2018.02.007, 2018.

Killham, K. and Firestone, M. K.: Salt Stress Control of Intracellular Solutes in Streptomycetes Indigenous to Saline Soils, Appl. Environ. Microb., 47, 301-306, https://doi.org/10.1128/aem.47.2.301-306.1984, 1984.

King, A. E. and Blesh, J.: Crop rotations for increased soil carbon: perenniality as a guiding principle, Ecol. Appl., 28, 249-261, https://doi.org/10.1002/eap.1648, 2018.

Kramer, S., Marhan, S., Haslwimmer, H., Ruess, L., and Kandeler, E.: Temporal variation in surface and subsoil abundance and function of the soil microbial community in an arable soil, Soil Biol. Biochem., 61, 76-85, https://doi.org/10.1016/j.soilbio.2013.02.006, 2013.

Lehman, R. M., Osborne, S. L., and Duke, S. E.: Diversified No-Till Crop Rotation Reduces Nitrous Oxide Emissions, Increases Soybean Yields, and Promotes Soil Carbon Accrual, Soil Sci. Soc. Am. J., 81, 76-83, https://doi.org/10.2136/sssaj2016.01.0021, 2017.

Li, X., Miller, A. E., Meixner, T., Schimel, J. P., Melack, J. M., and Sickman, J. O.: Adding an empirical fac- 
tor to better represent the rewetting pulse mechanism in a soil biogeochemical model, Geoderma, 159, 440-451, https://doi.org/10.1016/j.geoderma.2010.09.012, 2010.

Linn, D. M. and Doran, J. W.: Aerobic and Anaerobic Microbial Populations in No-till and Plowed Soils, Soil Sci. Soc. Am. J., 48, 794-799, https://doi.org/10.2136/sssaj1984.03615995004800040019x, 1984.

McDaniel, M. D. and Grandy, A. S.: Soil microbial biomass and function are altered by 12 years of crop rotation, SOIL, 2, 583599, https://doi.org/10.5194/soil-2-583-2016, 2016.

McDaniel, M. D., Tiemann, L. K., and Grandy, A. S.: Does agricultural crop diversity enhance soil microbial biomass and organic matter dynamics? A meta-analysis, Ecol. Appl., 24, 560570, https://doi.org/10.1890/13-0616.1, 2014.

Mooshammer, M., Hofhansl, F., Frank, A. H., Wanek, W., Hämmerle, I., Leitner, S., Schnecker, J., Wild, B., Watzka, M., Keiblinger, K. M., Zechmeister-Boltenstern, S., and Richter, A.: Decoupling of microbial carbon, nitrogen, and phosphorus cycling in response to extreme temperature events, Sci. Adv., 3, e1602781, https://doi.org/10.1126/sciadv.1602781, 2017.

Muhr, J., Goldberg, S. D., Borken, W., and Gebauer, G.: Repeated drying-rewetting cycles and their effects on the emission of $\mathrm{CO}_{2}$, $\mathrm{N}_{2} \mathrm{O}, \mathrm{NO}$, and $\mathrm{CH}_{4}$ in a forest soil, J. Plant Nutr. Soil Sc., 171, 719-728, https://doi.org/10.1002/jpln.200700302, 2008.

Paul, E. A., Morris, S. J., and Bohm, S.: The determination of soil $\mathrm{C}$ pool sizes and turnover rates: Biophysical fractionation and tracers, in: Assessment Methods for Soil Carbon, edited by: Lal, R., Kimble, J. M., Follett, R. F., and Stewart, B. A., 193-206, https://doi.org/10.1201/9781482278644, CRC Press, Boca Raton, Florida, USA, 2001.

Randle-Boggis, R. J., Ashton, P. D., and Helgason, T.: Increasing flooding frequency alters soil microbial communities and functions under laboratory conditions, Microbiologyopen, 7, e00548, https://doi.org/10.1002/mbo3.548, 2018.

R Development Core Team: R: A language and environment for statistical computing, available at: http://www.r-project.org/ (last access: 16 August 2021), 2013.

Saidy, A. R., Smernik, R. J., Baldock, J. A., Kaiser, K., and Sanderman, J.: Microbial degradation of organic carbon sorbed to phyllosilicate clays with and without hydrous iron oxide coating, Eur. J. Soil Sci., 66, 83-94, https://doi.org/10.1111/ejss.12180, 2015.

Schimel, J. P.: Life in Dry Soils: Effects of Drought on Soil Microbial Communities and Processes, Annu. Rev. Ecol. Evol. Syst., 49, 409-432, https://doi.org/10.1146/annurev-ecolsys-110617062614, 2018.

Schmidt, M. W. I., Torn, M. S., Abiven, S., Dittmar, T., Guggenberger, G., Janssens, I. A., Lehmann, J., Manning, D. A. C., Nannipieri, P., Rasse, D. P., Kleber, M., and Ko, I.: Persistence of soil organic matter as an ecosystem property, Nature, 478, 4956, https://doi.org/10.1038/nature10386, 2011.

Schnecker, J.: Soil data, Phaidra [data set], https://doi.org/11353/10.1220845, 2021a.

Schnecker, J.: Respiration rates, Phaidra [data set], https://doi.org/11353/10.1220845, 2021b.

Schnecker, J., Wild, B., Takriti, M., Eloy Alves, R. J., Gentsch, N., Gittel, A., Hofer, A., Klaus, K., Knoltsch, A., Lashchinskiy, N., Mikutta, R., and Richter, A.: Microbial community composition shapes enzyme patterns in topsoil and subsoil horizons along a latitudinal transect in Western Siberia, Soil Biol. Biochem., 83, 106-115, https://doi.org/10.1016/j.soilbio.2015.01.016, 2015.

Schnecker, J., Bowles, T., Hobbie, E. A., Smith, R. G., and Grandy, A. S.: Substrate quality and concentration control decomposition and microbial strategies in a model soil system, Biogeochemistry, 144, 47-59, https://doi.org/10.1007/s10533-019-00571-8, 2019.

Smith, K. A., Ball, T., Conen, F., Dobbie, K. E., Massheder, J., and Rey, A.: Exchange of greenhouse gases between soil and atmosphere: interactions of soil physical factors and biological processes, Eur. J. Soil Sci., 54, 779-791, https://doi.org/10.1046/j.1351-0754.2003.0567.x, 2003.

Steinweg, J. M., Dukes, J. S., Paul, E. A., and Wallenstein, M. D.: Microbial responses to multi-factor climate change: effects on soil enzymes, Front. Microbiol., 4, 146, https://doi.org/10.3389/fmicb.2013.00146, 2013.

Stocker, T. F., Qin, D., Plattner, G.-K., Tignor, M. M. B., Allen, S. K., Boschung, J., Nauels, A., Xia, Y., Bex, V., Midgley, P. M., Alexander, L. V., Allen, S. K., Bindoff, N. L., Breon, F.M., Church, J. A., Cubasch, U., Emori, S., Forster, P., Friedlingstein, P., Gillett, N., Gregory, J. M., Hartmann, D. L., Jansen, E., Kirtman, B., Knutti, R., Kumar Kanikicharla, K., Lemke, P., Marotzke, J., Masson-Delmotte, V., Meehl, G. A., Mokhov, I. I., Piao, S., Plattner, G.-K., Dahe, Q., Ramaswamy, V., Randall, D., Rhein, M., Rojas, M., Sabine, C., Shindell, D., Stocker, T. F., Talley, L. D., Vaughan, D. G., Xie, S.-P., Allen, M. R., Boucher, O., Chambers, D., Hesselbjerg Christensen, J., Ciais, P., Clark, P. U., Collins, M., Comiso, J. C., Vasconcellos de Menezes, V., Feely, R. A., Fichefet, T., Fiore, A. M., Flato, G., Fuglestvedt, J., Hegerl, G., Hezel, P. J., Johnson, G. C., Kaser, G., Kattsov, V., Kennedy, J., Klein Tank, A. M. G., Le Quere, C., Myhre, G., Osborn, T., Payne, A. J., Perlwitz, J., Power, S., Prather, M., Rintoul, S. R., Rogelj, J., Rusticucci, M., Schulz, M., Sedlacek, J., Stott, P. A., Sutton, R., Thorne, P. W., and Wuebbles, D.: Climate Change 2013. The Physical Science Basis. Working Group I Contribution to the Fifth Assessment Report of the Intergovernmental Panel on Climate Change - Abstract for decision-makers; Changements climatiques 2013. Les elements scientifiques. Contribution du groupe de travail I au cinquieme rapport d'evaluation du groupe d'experts intergouvernemental sur l'evolution du CLIMAT - Resume a l'intention des decideurs, Cambridge University Press, Cambridge, United Kingdom and New York, NY, USA, 1535 pp., 2013.

Tecon, R. and Or, D.: Biophysical processes supporting the diversity of microbial life in soil, FEMS Microbiol. Rev., 41, 599-623, https://doi.org/10.1093/femsre/fux039, 2017.

Tiemann, L. K. and Billings, S. A.: Changes in variability of soil moisture alter microbial community $\mathrm{C}$ and $\mathrm{N}$ resource use, Soil Biol. Biochem., 43, 1837-1847, https://doi.org/10.1016/j.soilbio.2011.04.020, 2011.

Tiemann, L. K. and Billings, S. A.: Tracking $\mathrm{C}$ and $\mathrm{N}$ flows through microbial biomass with increased soil moisture variability, Soil Biol. Biochem., 49, 11-22, https://doi.org/10.1016/j.soilbio.2012.01.030, 2012.

Tiemann, L. K., Grandy, A. S., Atkinson, E. E., Marin-Spiotta, E., and McDaniel, M. D.: Crop rotational diversity enhances belowground communities and functions in an agroe- 
cosystem, edited by D. Hooper, Ecol. Lett., 18, 761-771, https://doi.org/10.1111/ele.12453, 2015.

Unger, S., Máguas, C., Pereira, J. S., David, T. S., and Werner, C.: The influence of precipitation pulses on soil respiration - Assessing the "Birch effect" by stable carbon isotopes, Soil Biol. Biochem., 42, 1800-1810, https://doi.org/10.1016/j.soilbio.2010.06.019, 2010.

Vance, E. D., Brookes, P. C., and Jenkinson, D. S.: Microbial biomass measurements in forest soils: The use of the chloroform fumigation-incubation method in strongly acid soils, Soil Biol. Biochem., 19, 697-702, https://doi.org/10.1016/00380717(87)90051-4, 1987.

Venter, Z. S., Jacobs, K., and Hawkins, H. J.: The impact of crop rotation on soil microbial diversity: A meta-analysis, Pedobiologia, 59, 215-223, https://doi.org/10.1016/j.pedobi.2016.04.001, 2016.

Vukicevich, E., Lowery, T., Bowen, P., Úrbez-Torres, J. R., and Hart, M.: Cover crops to increase soil microbial diversity and mitigate decline in perennial agriculture. A review, Agron. Sustain. Dev., 36, 1-14, https://doi.org/10.1007/s13593-016-0385-7, 2016.
Weil, R. R., Islam, K. R., Stine, M. A., Gruver, J. B., and Samson-Liebig, S. E.: Estimating active carbon for soil quality assessment: A simplified method for laboratory and field use, Am. J. Alternative Agr., 18, 3-17, https://doi.org/10.1079/AJAA2003003, 2003.

White, K. E., Cavigelli, M. A., Conklin, A. E., and Rasmann, C.: Economic Performance of Long-term Organic and Conventional Crop Rotations in the Mid-Atlantic, Agron. J., 111, 1358-1370, https://doi.org/10.2134/agronj2018.09.0604, 2019.

Wood, J. M.: Bacterial responses to osmotic challenges, J. Gen. Physiol., 145, 381-388, https://doi.org/10.1085/jgp.201411296, 2015. 